\title{
Solid-phase enzyme-immunoassay for detection of hepatitis B surface antigen
}

\author{
G. WOLTERS, L. KUIJPERS, J. KAČAKI, AND A. SCHUURS \\ From the Organon Scientific Development Group, Oss, The Netherlands
}

SYNOPSIS The preliminary results of a solid-phase enzyme-immunoassay (EIA) for the detection of hepatitis $\mathrm{B}$ surface antigen $\left(\mathrm{HB}_{\mathrm{s}} \mathrm{Ag}\right)$ are presented. This method has been compared with the solid-phase radioimmunoassay (RIA) for $\mathrm{HB}_{\mathrm{s}} \mathrm{Ag}$ in dilution series of four $\mathrm{HB}_{\mathrm{s}} \mathrm{Ag}$ positive sera, four national reference panels (The Laboratory Panel of the Central Laboratory of the Blood Transfusion Service of the Netherlands Red Cross, USA BOB Reference Panels Nos. 2 and 3, and the 1st Panel of the National Reference Centre for Virus Hepatitis at the Institute of Hygiene of the University of Göttingen, West Germany). In addition, the two test methods were compared in a weekly (up to 16 weeks) follow-up of 14 patients with acute viral hepatitis B. It was seen that, both by reading EIA test results with the naked eye and by colorimetric reading, the sensitivity and specificity of this test method compared very favourably with those of the RIA. EIA may have a slightly lower sensitivity than RIA for the subtype $a d$, while its sensitivity for the subtype ay may be slightly higher than that of RIA. These minor sensitivity differences may be due to the specificity profiles of the antisera used.

Since the discovery of the relationships between Australia antigen, now called hepatitis B surface antigen $\left(\mathrm{HB}_{\mathrm{s}} \mathrm{Ag}\right)$, and serum hepatitis (type $\mathrm{B}$ hepatitis) a number of immunochemical techniques with different specificity, sensitivity, and practicability for the detection of $\mathrm{HB}_{\mathrm{s}} \mathrm{Ag}$ have been described. A recent survey of these methods is given in a WHO Technical Report (World Health Organization, 1975). For a number of years our laboratory has worked on the development of a new and sensitive immunochemical technique, the enzymeimmunoassay (EIA) (van Weemen and Schuurs, 1971, 1972; van Weemen et al, 1974). This method has also been studied by several other groups of investigators, particularly by Engvall and Perlmann (1971, 1972) and Engvall et al (1971). The present paper describes the application of a solid-phase enzyme-immunoassay for the detection of ${ }_{,} \mathrm{HB}_{\mathrm{s}} \mathrm{Ag}$.

\section{Materials and methods}

HEPATITIS B SURFACE ANTIGEN

Purified $\mathrm{HB}_{\mathrm{s}} \mathrm{Ag}$ was obtained from positive donor plasmas in the way described by Schuurs and Wolters (1975).

SHEEP ANTI-HBS GAMMAGLOBULIN

Sheep were immunized by repeated intramuscular Received for publication 24 February 1976 injections of purified $\mathrm{HB}_{\mathrm{s}} \mathrm{Ag}$ in complete Freund's adjuvant at two-week intervals until a reciprocal titre of antibody to $\mathrm{HB}_{\mathrm{s}} \mathrm{Ag}$ (anti-HB $\mathrm{H}_{\mathrm{s}}$ ) of $\geqslant 512$ in a standard immunodiffusion set-up was attained with both subtype $a y$ and $a d$. The resulting antiserum was tested by immunodiffusion against normal human serum (undiluted and diluted from 1:2 to $1: 32)$. The antiserum was absorbed with insolubilized normal human serum proteins until no antibodies to human serum proteins could be detected. The gammaglobulin fraction was precipitated with $14 \%$ (w/v) $\mathrm{Na}_{2} \mathrm{SO}_{4}$, and the precipitate was dissolved in $0.0175 \mathrm{M}$ phosphate buffer $\mathrm{pH} 7.6$ and dialysed against the same buffer.

ANTIBODY-COATED MICROTITRE PLATES

The wells of Microtiter ${ }^{\circledR}$ plates (Cooke) were filled with $0.1 \mathrm{ml}$ sheep anti-HB $\mathrm{H}_{\mathrm{s}}$ gammaglobulin fraction having a protein concentration of 0.03 $\mathrm{mg} / \mathrm{ml}$. The liquid was removed from the plates after overnight incubation at $4^{\circ} \mathrm{C}$, the plates were

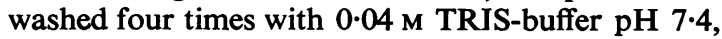
dried over silicagel, and stored at $4^{\circ} \mathrm{C}$ in the presence of silicagel.

ANTIBODY-ENZYME CONJUGATE

Horse-radish peroxidase (Miles; RZ 3.0) was linked to sheep anti-HB gammaglobulin in a protein ratio of 4:1 by the 'two-step' method of Avrameas 
and Ternynck (1971) using $2 \%$ glutaraldehyde. The (anti-HB S $_{\mathrm{s}}$-enzyme conjugate was recovered by precipitation with $14 \%(\mathrm{w} / \mathrm{v}) \mathrm{Na}_{2} \mathrm{SO}_{4}$. The conjugate was dissolved in a $\mathbf{0 . 2} \mathrm{M}$ TRIS-buffer of $\mathrm{pH} \mathbf{7 \cdot 4}$ and used in a concentration designed to give an average extinction of about $0 \cdot 100$ in the test of the negative control (see below).

\section{CHROMOGENIC COMPOUND FOR THE ENZYME} REACTION

Ortho-phenylene diamine was regarded as the most suitable chromogen in spite of its light-sensitivity. In comparison with a number of other compounds examined it had the following advantages:

(a) the most sensitive test results were obtained;

(b) the colour development was easily stopped;

(c) the coloured reaction product was stable for many hours and did not precipitate, not even at high concentrations.

HUMAN ANTI-HBs

Human anti-HB $\mathrm{H}_{\mathrm{s}}$ used for confirmation of presumptive positive sera was obtained from the Central Laboratory of the Blood Transfusion Service of the Netherlands Red Cross (CLB). On the basis of a test as described under 'Detection of anti-HB s' $_{\mathbf{s}}$ (see below), the reagent was used in a dilution of $1: 10$. It could completely neutralize positive reactions of test samples giving extinctions of 1.9 or lower in the screening test.

NORMAL HUMAN SERUM

Pools of at least five normal human sera were used for negative controls and for sham neutralization in the confirmatory test. They were selected on the basis of the absence of $\mathrm{HB}_{\mathrm{s}} \mathrm{Ag}$ in radioimmunoassay

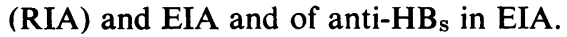

ORIGIN OF TEST SAMPLES

The Laboratory panel of the Central Laboratory of the Blood Transfusion Service of the Netherlands Red Cross (CLB panel) was kindly made available to us by Dr. H. Reesink. BOB Reference panels Nos. 2 and 3 were kindly supplied by the United States Department of Health, Education and Welfare, Public Health Service, Bureau of Biologics, Food and Drug Administration. The 1st Panel of the National Reference Centre for Virus Hepatitis at the Institute of Hygiene of the University of Göttingen, West Germany was obtained by courtesy of Professor R. Thomssen.

Serial serum samples of hospitalized patients with acute viral hepatitis type B were collected weekly for up to 16 weeks after the initial symptoms and kindly made available by Professor V. Mudrić, School of Medicine, University of Novi Sad,
Yugoslavia ${ }^{1}$. Fresh donor sera (not older than $30^{\circ}$ hours) were kindly supplied by the CLB (Dr. Họ Reesink).

PERFORMANCE OF THE SCREENING TEST A $0.1 \mathrm{ml}$ test sample (or a positive or negative control) was pipetted into an (anti-HB $\mathrm{H}_{\mathrm{s}}$ )-coated $\overline{\bar{p}}$ well of a Microtiter ${ }^{\circledR}$ plate and incubated for ${ }^{\mathbb{D}}$ 2 hours at $37^{\circ} \mathrm{C}$. The wells were aspirated and washedo three times with $0 \cdot 2 \mathrm{M}$ TRIS-buffer $\mathrm{pH} 7 \cdot 4$.

$0.1 \mathrm{ml}$ of the antibody-conjugate solution was then added to each well, incubated for 2 hours at $\vec{\omega}$ $37^{\circ} \mathrm{C}$, and removed by aspiration. The wells were afterwards washed four times with the same TRIS $\frac{\widehat{0}}{0}$ buffer.

$0.1 \mathrm{ml}$ of a freshly prepared solution of o-phenylene diamine $(0.4 \mathrm{mg} / \mathrm{ml})$ and urea peroxide 0 $(0.2 \mathrm{mg} / \mathrm{ml})$ in a phosphate-citrate buffer of $\mathrm{pH} 5.0 \mathrm{~N}$ was added to each well and incubated in the dark ${ }_{0}^{\omega}$ for 50 minutes at room temperature. The enzyme reaction was stopped by adding $0.05 \mathrm{ml} 4 \mathrm{~N}$ sul- $\overrightarrow{-}$ phuric acid.

The yellow colour of the product of the enzyme음 reaction was read by eye against a diffuse white $\stackrel{\Phi}{-}$ light source placed underneath the Microtiter ${ }^{\circledR} \overrightarrow{0}$ plate and/or by measurement of the extinction $\Omega t / 2$ $492 \mathrm{~nm}$ in a microcuvette of a Vitatron colo meter.

If read by eye, a sample was called positive whe its colour was stronger than that of the negative control. (Usually, extinction values below $0 \cdot 200 \frac{\mathrm{D}}{\mathrm{O}}$ could not be distinguished by eye from those of the 2 negative control having an extinction of about $\overrightarrow{\vec{O}}$ $0 \cdot 100$.) When measuring extinction, the ratio:

$$
\frac{E_{\text {test sample }}-E_{\text {blank II }}}{E_{\text {blank I }}-E_{\text {blank II }}} \geqslant 2 \cdot 1
$$

was considered to represent a positive reaction. $\frac{0}{3}$ $E_{\text {blank I }}$ was the average extinction of five negative $\frac{3}{6}$ serum controls, $E_{\text {blank II }}$ the extinction of $0 \cdot 1 \mathrm{ml}$ of a solution containing o-phenylene diamine and $₹$ urea peroxide as described above, mixed with $0.05 \mathrm{ml}$ 음 $4 \mathrm{~N}$ sulphuric acid.

A ratio of less than $2 \cdot 1$ and more than 1.5 was considered to be equivocal $( \pm)$.

CONFIRMATION OF PRESUMPTIVE POSITIVES Samples found positive in the screening test described $N$ above were serially diluted in $0.9 \% \mathrm{NaCl}$ (undiluted to $1: 32$ with a dilution factor of 2 ) and subjected too a neutralization procedure: $100 \mu \mathrm{l}$ of each dilution

'The clinical details, as well as the correlation of the enzyme immunoassay results with the clinical picture, will be pub- $\mathbb{D}$ lished later by Professor Mudric. 
of the sample was mixed with $10 \mu$ l of human anti$\mathrm{HB}_{\text {s }}$ and incubated for 1 hour at $37^{\circ} \mathrm{C}$ followed by 16 hours at $4^{\circ} \mathrm{C}$. A sham neutralization was done with non-immune human serum as a control on an identical dilution series of the same sample. After the neutralization procedure each dilution was tested according to the screening test procedure. Untreated (undiluted) samples were simultaneously retested in order to check the result of the screening.

If read by eye, a titre reduction of at least two dilution steps, after anti-HB $\mathrm{B}_{\mathbf{s}}$ treatment, as compared with the control treatment was considered specifically positive. If no endpoint was found, but a reduction of colour was clearly visible in comparison with the control, the extinctions were measured for a final conclusion (see below). Only very strong positives had to be retested after making a further dilution series of the sample starting at $1: 32$. Normal human serum (free from $\mathrm{HB}_{\mathbf{s}} \mathrm{Ag}$ and anti- $\mathrm{HB}_{\mathbf{s}}$ ) was then used as diluent in order to avoid non-specific binding of conjugate to the solid phase due to the absence of sufficient inert proteins.

If read colorimetrically, reduction of the extinction by anti-HB by at least $50 \%$, in comparison with the control, was considered to confirm a specific positive reaction.

\section{DETECTION OF ANTI-HBS}

Serial dilutions of two $\mathrm{HB}_{\mathbf{s}} \mathrm{Ag}$-containing sera, of subtype $a y$ and subtype $a d$ respectively, were made in $0.9 \%$ sodium chloride containing either $3 \%$ bovine serum albumin or $10 \%$ normal human serum proved to be free from anti-HB $\mathrm{H}_{\mathrm{s}}$ and $\mathrm{HB}_{\mathrm{s}} \mathrm{Ag}$.

Ten microlitres of each dilution was mixed with $0.1 \mathrm{ml}$ of the serum to be tested for anti-HB $\mathrm{H}$. The mixture was incubated for 1 hour at $37^{\circ} \mathrm{C}$ followed by 16 hours at $4^{\circ} \mathrm{C}$.
Any reduction of the titre of the $\mathrm{HB}_{\mathrm{s}} \mathrm{Ag}$-containing sera, when compared with a proper control, was regarded as an indication that anti-HB $\mathrm{H}_{\mathrm{s}}$ was present in the serum tested.

\section{ADDITIONAL TECHNIQUES FOR HBsAg DETERMINATION}

Radioimmunoassay (RIA):Ausria II (Abbott Laboratories, Chicago, Ill, USA) was used according to the manufacturer's instructions. Reversed passive haemagglutination (rHA): Hepanosticon ${ }^{\circledR}$ (Organon Teknika, Oss, The Netherlands) was performed as described by Schuurs and Kačaki (1974).

Subspecificities of $\mathrm{HB}_{\mathrm{s}} \mathrm{Ag}$ positive sera were determined by immunodiffusion as described by van Kooten Kok-Doorschodt et al (1972).

\section{Results}

\section{SENSITIVITY DETERMINED IN DILUTION SERIES}

Serial dilutions of $\mathrm{HB}_{\mathrm{s}} \mathrm{Ag}$-containing serum in normal human serum (free from $\mathrm{HB}_{\mathrm{s}} \mathrm{Ag}$ and anti$\mathrm{HB}_{\mathrm{s}}$ ) were tested by RIA and EIA in a randomized order. Each subspecificity $a d$ and $a y$ was represented by two different sera. Each positive serum was studied using two different normal human sera as a dilution fluid. The results are summarized in tables $I$ and II and in figure 1.

\section{SERUM PANELS}

\section{German reference panel}

This panel consisted of 50 samples (two positive sera in 20 dilutions each and 10 negative samples). It had been previously tested by 34 West German laboratories using solid phase RIA (Gerlich et al, 1976). This panel was tested in our laboratory under

\begin{tabular}{|c|c|c|c|c|c|c|c|}
\hline \multirow{3}{*}{$\begin{array}{l}\text { Dilution } \\
\text { factor }\end{array}$} & & \multirow{2}{*}{\multicolumn{2}{|c|}{$\frac{R I A}{\text { Ratio }}$}} & \multicolumn{4}{|l|}{$E I A$} \\
\hline & & & & \multicolumn{2}{|c|}{ Ratio } & \multicolumn{2}{|c|}{ Eye-reading ${ }^{2}$} \\
\hline & & 1 & 2 & 1 & 2 & 1 & 2 \\
\hline $\begin{array}{l}2^{11} \\
2^{12} \\
2^{13} \\
2^{14} \\
2^{15}\end{array}$ & & $\begin{array}{l}6 \cdot 0 \\
3 \cdot 3 \\
2 \cdot 0 \\
2 \cdot 3 \\
1 \cdot 6\end{array}$ & $\begin{array}{l}4.4 \\
3.3 \\
1.9 \\
1.6 \\
1.4\end{array}$ & $\begin{array}{r}12.0 \\
5.5 \\
3.8 \\
1.5 \\
1.4\end{array}$ & $\begin{array}{l}9 \cdot 9 \\
6 \cdot 7 \\
3 \cdot 1 \\
1 \cdot 6 \\
1 \cdot 2\end{array}$ & $\begin{array}{l}++ \\
\pm- \\
+- \\
-- \\
--\end{array}$ & $\begin{array}{l}++ \\
++ \\
++ \\
\pm- \\
--\end{array}$ \\
\hline $\begin{array}{l}2^{6} \\
2^{7} \\
2^{8} \\
2^{9} \\
2^{10} \\
2^{11}\end{array}$ & - & $\begin{array}{l}2.8 \\
2.6 \\
1.8 \\
1.2 \\
0.9 \\
1.1\end{array}$ & $\begin{array}{l}3 \cdot 4 \\
2 \cdot 5 \\
2 \cdot 2 \\
1 \cdot 5 \\
1 \cdot 3 \\
1 \cdot 3\end{array}$ & $\begin{array}{l}9 \cdot 2 \\
5 \cdot 3 \\
2 \cdot 3 \\
2 \cdot 2 \\
1 \cdot 2 \\
0 \cdot 9\end{array}$ & $\begin{array}{r}13.0 \\
5.6 \\
2.6 \\
2.0 \\
1.2 \\
0.5\end{array}$ & $\begin{array}{l}++ \\
\pm- \\
\pm- \\
-- \\
-- \\
--\end{array}$ & $\begin{array}{l}++ \\
++ \\
-- \\
-- \\
-- \\
--\end{array}$ \\
\hline
\end{tabular}

Table I Titration of two different $\mathrm{HB} \mathrm{B}_{\mathrm{s}} \mathrm{Ag}$ positive sera of subtype ay

'Dilution series 1 and 2 were made in different normal human sera

'Naked-eye readings were made by two unbiased individuals 
Table II Titration of two different $H B_{\mathrm{s}} A g$ positive sera of subtype ad

${ }^{1}$ Dilution series 1 and 2 were made in different normal human sera

${ }^{2}$ Naked-eye readings were made by two unbiased individuals

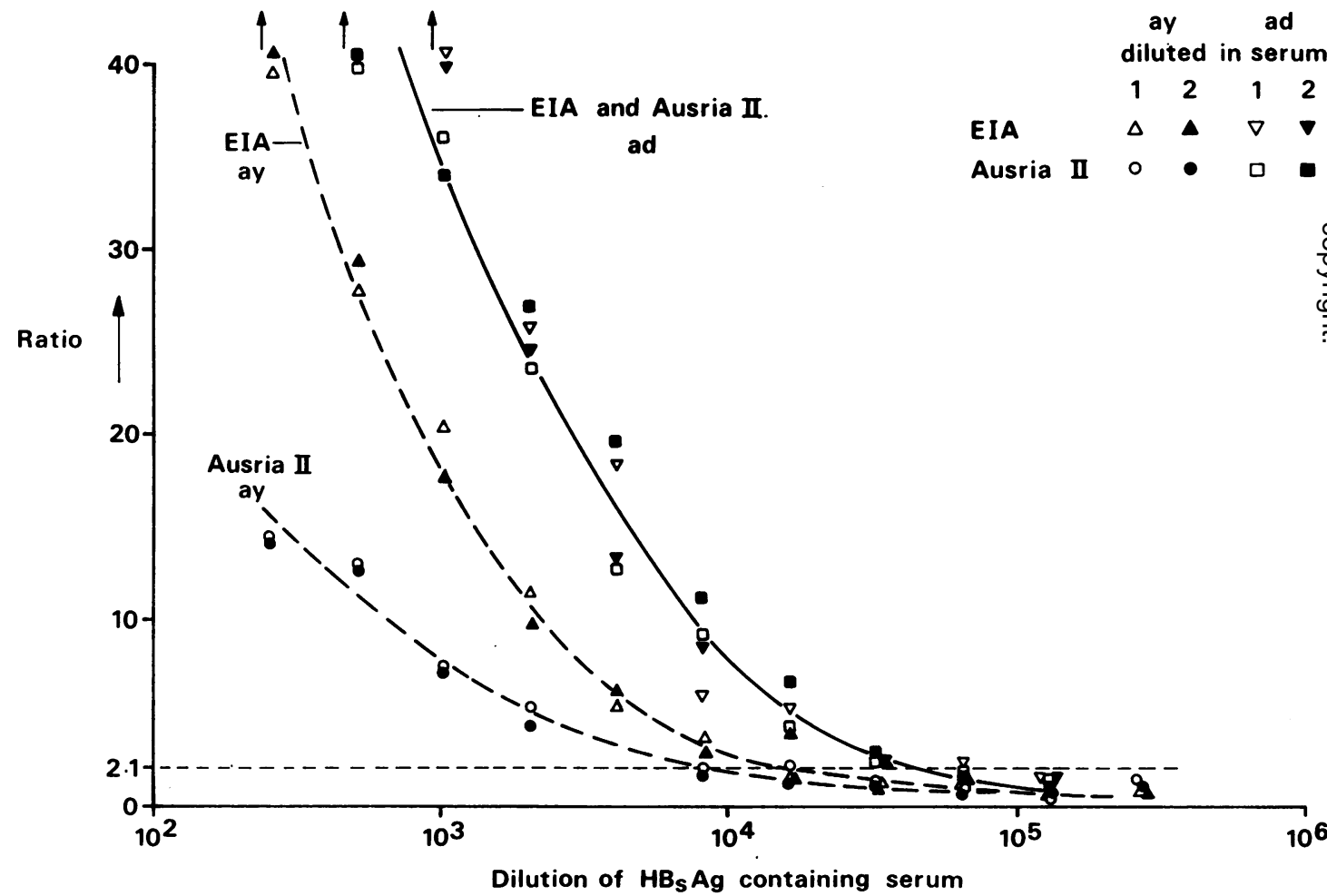

Fig 1 Dose-response curve of $\mathrm{HB}_{\mathrm{B}} \mathrm{Ag}$ in EIA (extinction measurement) and RIA (Ausria II). The curves are based on data partially presented in tables I and II. The two results of the ad subtype in EIA and RIA are represented by the same curve.

code, which was held by Professor R. Thomssen. The results are given in table III. After breaking the code, it was seen that the concentration of $\mathrm{HB}_{\mathrm{s}} \mathrm{Ag}$ ranged from $16000 \mathrm{ng} / \mathrm{ml}$ to $0.03 \mathrm{ng} / \mathrm{ml}$ for subtype ad and from $10000 \mathrm{ng} / \mathrm{ml}$ to $0.02 \mathrm{ng} / \mathrm{ml}$ for subtype ay (Gerlich et al, 1976). The EIA technique detected at least $10.5 \mathrm{ng} / \mathrm{ml}$ of the subtype ad and at least $2 \cdot 4 \mathrm{ng} / \mathrm{ml}$ of the subtype ay. 


\begin{tabular}{|c|c|c|c|c|c|}
\hline No. of samples & Subtype $e^{1}$ & Dilutions $^{1}$ & $n g H B_{8} A g / m l^{1}$ & $R I A(\%+)^{2}$ & $E I A^{3}$ \\
\hline $\begin{array}{r}10 \\
1 \\
1 \\
1 \\
7\end{array}$ & ad & $\begin{array}{l}1 \quad-2^{9} \\
2^{10} \\
2^{11} \\
2^{12} \\
2^{13}-2^{19}\end{array}$ & $\begin{array}{l}16000-23 \cdot 5 \\
10 \cdot 5 \\
3 \cdot 7 \\
1 \cdot 2 \\
<1 \cdot<0.03\end{array}$ & $\begin{array}{l}97-100 \\
94 \\
78 \\
15 \\
6-0\end{array}$ & $\begin{array}{l}+ \\
+ \\
\pm \\
-\end{array}$ \\
\hline $\begin{array}{r}11 \\
1 \\
1 \\
1 \\
6\end{array}$ & $a y$ & $\begin{array}{l}1-2^{10} \\
2^{11} \\
2^{12} \\
2^{13} \\
2^{14}-2^{19}\end{array}$ & $\begin{array}{l}10000-10 \\
4.9 \\
2.4 \\
<1.2 \\
<0.6-<0.02\end{array}$ & $\begin{array}{l}91-100 \\
39 \\
12 \\
0 \\
0\end{array}$ & $\begin{array}{l}+ \\
+ \\
+ \\
\pm \\
-\end{array}$ \\
\hline $\begin{array}{l}1^{4} \\
9\end{array}$ & - & $\begin{array}{l}1 \\
1\end{array}$ & $\begin{array}{l}<5 \\
<5\end{array}$ & $\begin{array}{l}0 \\
0\end{array}$ & \pm \\
\hline Total 50 & & & & & \\
\hline
\end{tabular}

Table III German National Reference Panel

${ }^{1}$ As reported by Gerlich et al (1976)

'As reported by Gerlich et al (1976); percentage of 34 participating laboratories that reported a positive result

${ }^{3}$ Colorimetric reading

"Contains anti-HBs

\section{CLB panel}

This panel consisted of $70 \mathrm{HB}_{\mathrm{s}} \mathrm{Ag}$ positive and $30 \mathrm{HB}_{\mathrm{s}} \mathrm{Ag}$ negative sera, as determined by Ausria II. The results obtained in this panel by EIA are given in table IV. The sensitivity of EIA (eye reading) was found to be the same as that of RIA.

\begin{tabular}{cccc}
\hline & & $R I A$ & \\
\cline { 3 - 4 } & & + & - \\
\hline EIA & + & 70 & 0 \\
rHA & + & 0 & 30 \\
& - & 65 & 0 \\
\hline
\end{tabular}

Table IV Results of the examination of the CLB panel

BOB panel No. 2

All positive samples (32) labelled $A, B$, and $C$ were found to be positive by EIA, even when read with the naked eye. Two 'borderline positives' labelled (C) and the 16 negative samples of this panel were found to be negative in EIA.

\section{BOB panel No. 3}

All positive samples (17) labelled $A, B$, and $C$ were found to be positive in EIA both by eye reading and colorimetrically. Both positives labelled (C), which are described by the BOB as 'occasionally reactive by third generation test methods' (such as RIA), were found to be positive in one EIA test and equivocal in another.

The samples labelled $D$, which are described as 'non-reactive by current test methods but contain low levels of $\mathrm{HB}_{\mathbf{s}} \mathrm{Ag}$ ', were found to be negative in EIA.
The samples labelled negative (3) were also found to be negative.

\section{SERA OF ACUTE HEPATITIS B PATIENTS}

Serial serum samples of 14 patients with acute type B hepatitis were tested by counter-immunoelectrophoresis (CEP) ${ }^{1}$, rHA, RIA, and EIA.

The $\mathrm{HB}_{\mathrm{s}} \mathrm{Ag}$ subtype was ay in nine patients and ad in two, while in three cases the concentration was too low for subtyping. The results obtained are presented in table $\mathbf{V}$.

\begin{tabular}{|c|c|c|c|c|c|}
\hline \multirow{3}{*}{$\begin{array}{l}\text { Weeks after } \\
\text { beginning of } \\
\text { overt disease }\end{array}$} & \multicolumn{5}{|c|}{ Number of $\mathrm{HB}_{\mathrm{s}}$ Ag-positive reactions } \\
\hline & \multirow[t]{2}{*}{$C E P$} & \multirow[t]{2}{*}{$r H A$} & \multirow[t]{2}{*}{$R I A$} & \multicolumn{2}{|l|}{$E I A$} \\
\hline & & & & $E y e^{1}$ & $E x t^{2}$ \\
\hline 1 & 12 & 14 & 14 & 14 & 14 \\
\hline 2 & 6 & 14 & 14 & 14 & 14 \\
\hline 4 & 4 & 13 & 13 & 13 & 14 \\
\hline 6 & 2 & 11 & 11 & 11 & 11 \\
\hline 8 & 1 & 7 & 10 & 11 & 11 \\
\hline 10 & 0 & 2 & 5 & 7 & 7 \\
\hline 12 & 0 & 2 & 3 & 4 & 4 \\
\hline 14 & 0 & 1 & 1 & 3 & 3 \\
\hline 16 & 0 & 0 & 0 & 0 & 1 \\
\hline
\end{tabular}

Table $\mathrm{V}$ Number of positive reactions in 14 patients at various times after the beginning of overt disease

${ }^{1}$ Eye $=$ reading by naked eye

${ }^{2}$ Ext $=$ reading by extinction at $492 \mathrm{~nm}$

'All sera in this area where EIA positivity lasted longer than RIA positivity contained $\mathrm{HB}_{\mathrm{g}} \mathrm{Ag}$ exclusive of subtype ay

In the final stage of the antigenaemia, some patients still reacted positively in EIA, while RIA was already negative. This was found in five patients

${ }^{1}$ Performed by Professor V. Mudrić. 
if EIA results were measured colorimetrically, and in three patients if eye reading was used. Six patients showed episodes of negative reactions, as shown in figure 2. Most serum samples of these patients were negative in all tests during these periods. In three cases, however (patient 13 in week 9 , patient 14 in week 10, and patient 19 in week 12), the RIA was negative while the EIA was true positive. In summary, EIA was positive in eight sera (colorimetrically) and in six cases (read with the naked eye) where RIA was negative.

\section{FRESH BLOOD DONOR SERA}

Of 679 fresh sera from blood donors, three were found to be weakly positive in EIA screening (eye reading). None of the three could be neutralized by specific antiserum. All 679 sera were negative by rHA.

\section{Discussion}

The preliminary results obtained with EIA show that this new test for $\mathrm{HB}_{\mathrm{s}} \mathrm{Ag}$ has a sensitivity that compares very favourably with that of RIA.

Titration of $\mathrm{HB}_{\mathrm{s}} \mathrm{Ag}$ subtype ad resulted in similar dose-response curves for both test systems, while the slope of the curve obtained with subtype ay was steeper for EIA.

According to the data of the German Reference Panel, the detection level of $\mathrm{HB}_{\mathbf{s}} \mathrm{Ag}$ in EIA is at least $10.5 \mathrm{ng} / \mathrm{ml}$ for the ad subtype and $2.4 \mathrm{ng} / \mathrm{ml}$ for the ay subtype (table III). If the $\mathrm{HB}_{\mathrm{s}} \mathrm{Ag}$ concentration detected by at least $67 \%$ of the participating laboratories (Gerlich et al, 1976) is taken as the detection level of RIA, this level is in the order of $\vec{F}$ 3-4 $\mathrm{ng} / \mathrm{ml}$ for subtype $a d$ and $5-10 \mathrm{ng} / \mathrm{ml}$ for subtype ay.

This indicates that, with respect to subtype $a d, \frac{\text { ? }}{0}$ the sensitivity of EIA is lower than that of RIA by a factor of 2-3. On the contrary, with respect to $\overline{\bar{c}}$ subtype ay, the sensitivity of ElA is about three $\widehat{\Phi}$ times higher provided that a ratio of $\geqslant 2 \cdot 1$ (for both subtypes) is accepted as a positive cut-off value. In ${ }^{\infty}$ our view, this small difference in sensitivity towards $\overrightarrow{0}$ the two subtypes is rather a characteristic of the $\vec{A}$ immune reagents than of the test procedure. Antisera ${ }_{\sigma}^{\omega}$ with slightly different subtype specificity profiles are now being investigated.

It might be of interest to note here that the one ${ }^{\circ}$ 'negative' sample found equivocal in EIA (table III) $\vec{\circ}$

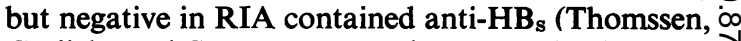
Gerlich, and Stamm, personal communication), so $\omega$ that one cannot completely exclude the presence of 을 $\mathrm{HB}_{\mathrm{s}} \mathrm{Ag}$ in immune complexes.

The results obtained with our dilution series $O$ (tables I and II and figure 1), the CLB panel (table $\stackrel{0}{0}$ IV), and the Reference panels Nos. 2 and 3 of the $\mathbb{\Phi}$ BOB confirm our impression that RIA and EIA $\overrightarrow{\vec{\varphi}}$ have a similar sensitivity.

From the follow-up of $\mathrm{HB}_{\mathbf{s}}$-antigenaemia in patients with acute hepatitis $\mathrm{B}$, it appears that EIA is even somewhat more sensitive than RIA by bot eye reading and extinction measurements. It is of interest that all of the six cases in which EIA (eye reading) was positive where the RIA was negative $\stackrel{\mathbb{Q}}{\mathscr{Q}}$ (table V) were of subtype ay.

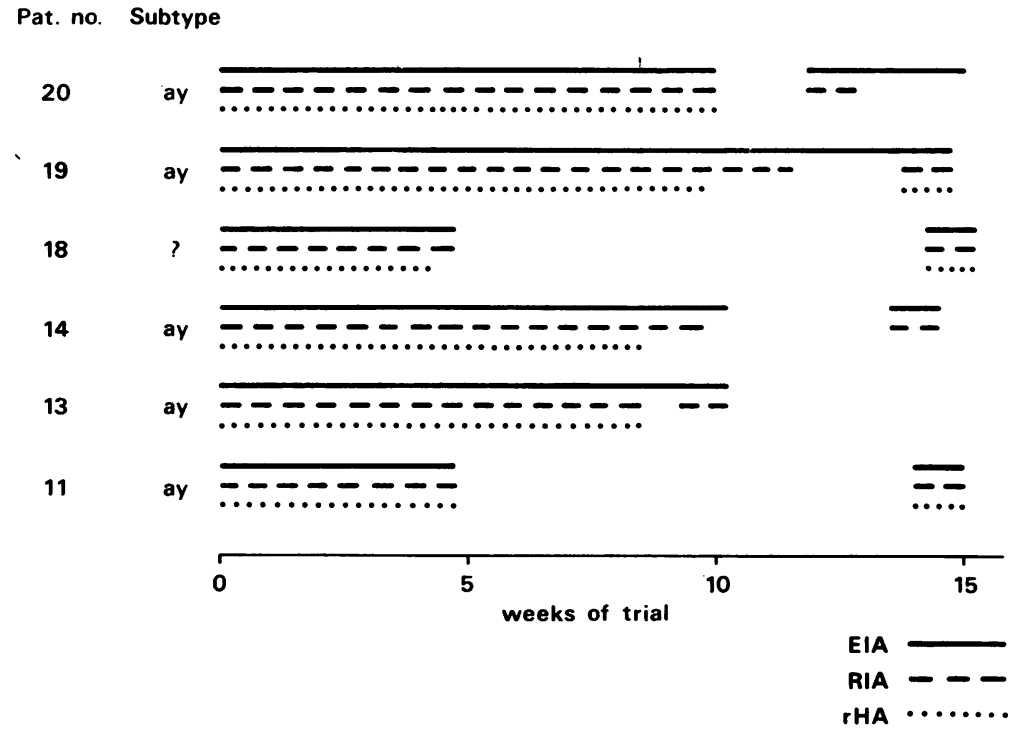

Fig 2 Results of longitudinal studies in six patients with hepatitis $B$ showing intermittent periods of $\mathrm{HB}$ A $A$ negative reactions. The three lines for each patient represent the positive results with EIA (both colorimetric and eye reading), $\mathrm{RIA}$, and $\mathrm{rHA}$ respectively. From patient 19 no serum sample taken in week 13 was available for testing. 
Concerning the interesting observation of the reappearance of $\mathrm{HB}_{\mathrm{s}} \mathrm{Ag}$ positivity by $\mathrm{ElA}$ and/or RIA during reconvalescence in six cases (figure 2), there were no clinical or biochemical changes observable in these patients which could explain this phenomenon (Mudrić and Vuković, 1975). Karvountzis et al (1975) described patients with two episodes of hepatitis which, however, were in no instance $\mathrm{HB}_{\mathrm{s}} \mathrm{Ag}$-positive in both episodes. An intermittent antigenaemia in chimpanzees infected with hepatitis B virus was found by Berquist et al (1975) in the early course of the disease. We are not aware of any publication dealing with more than one $\mathrm{HB}_{\mathbf{s}} \mathrm{Ag}$ positive episode in humans during acute hepatitis B such as we found. This phenomenon may be of epidemiological interest, since the majority of patients who showed this $\mathrm{HB}_{\mathbf{s}} \mathrm{Ag}$-negative period had already been discharged from the hospital as ' $\mathrm{HB}_{\mathrm{s}} \mathrm{Ag}$-negative'.

As far as the specificity of the EIA screening test is concerned we consider the incidence of three false positives found in the group of 679 fresh donor sera $(<0.5 \%)$ to be satisfactory.

The method for confirmation of presumptive positives was considered satisfactory. A series of dilutions of up to $1: 32$ was, in most cases, sufficient to obtain a conclusive result. All false positives were only weakly reactive in the screening. Strong presumptive positives always turned out to be true positive when tested at higher dilutions. Thus a confirmatory result of all false positives and most true positives is available on the day after screening.

We are now investigating a simpler confirmation procedure in which the predilution of sample is superfluous. The method is the same as the screening procedure except that an incubation with human anti-HB $\mathrm{B}_{\mathbf{s}}$ is inserted after the binding of $\mathrm{HB}_{\mathbf{s}} \mathrm{Ag}$ from the sample to the solid phase and before the addition of conjugate. Preliminary results are encouraging. Details will be presented elsewhere.

Tests for the detection of $\mathrm{HB}_{\mathrm{s}} \mathrm{Ag}$ in donor blood should be as sensitive as possible (cf. WHO Technical report, 1975). On the other hand, every screening test should also be as easy and practicable as possible. As is apparent from our results, EIA equals the sensitivity of RIA, thus belonging to the most sensitive test systems for $\mathrm{HB}_{\mathbf{s}} \mathrm{Ag}$ at present available.

The advantages of EIA over RIA are evident. Radio-iodinated reagents have a short shelf life and require expensive, rather sophisticated equipment for their detection. In an increasing number of countries the handling of radioactive material and the disposal of radioactive waste become subject to legal limitations.

EIA has none of these disadvantages but it does equal the sensitivity of RIA. This is already the case when the results are read by the naked eye. If a more objective reading and a somewhat higher sensitivity are desired, the use of colorimetric reading may contribute to this end.

In conclusion, EIA represents an easy and modern answer to the requirement of highly sensitive $\mathrm{HB}_{\mathbf{s}} \mathrm{Ag}$ detection, especially for less well equipped laboratories.

On the basis of the data described above we are organizing a multicentre efficacy trial of the test, the results of which will be published later.

\section{References}

Avrameas, S. and Ternynck, T. (1971). Peroxidase labelled antibody and Fab conjugates with enhanced intracellular penetration. Immunochemistry, 8, 1175-1179.

Berquist, K. R., Peterson, J. M., Murphy, B. L., Ebert, J. W. Maynard, J. E., and Purcell, R. H. (1975). Hepatitis B antigens in serum and liver of chimpanzees acutely infected with hepatitis B virus. Infect. and Immun., 12, 602-605.

Engvall, E., Jonsson, K., and Perlmann, P. (1971). Enzymelinked immunosorbent assay. II. Quantitative assay of protein antigen, immunoglobulin $G$, by means of enzymelabelled antigen and antibody-coated tubes. Biochim. biophys. Acta (Amst.), 251, 427-434.

Engvall, E. and Perlmann, P. (1971). Enzyme-linked immunosorbent assay (ELISA). Quantitative assay of immunoglobulin G. Immunochemistry, 8, 871-874.

Engvall, E. and Perlmann, P. (1972). Enzyme-linked immunosorbent assay, ELISA III. Quantitation of specific antibodies by enzyme-labeled anti-immunoglobulin in antigencoated tubes. J. Immunol., 109, 129-135.

Gerlich, W., Stamm, B., and Thomssen, R. (1976). Quantitative standardization in the detection of hepatitis B surface antigen. Results of a collaborative study including 74 laboratories. J. biol. Stand., in press.

Karvountzis, G. G., Mosley, J. W., and Redeker, A. G. (1975). Serologic characterization of patients with two episodes of acute viral hepatitis. Amer. J. Med., 58, 815-822.

van Kooten Kok-Doorschodt, H. J., van den Akker, R., and Gispen, R. (1972). Determination and distribution of two types of hepatitis-associated antigen. J. infect. Dis., 126, 117-122.

Mudrić, V. and Vuković, B. (1975). Personal communication.

Schuurs, A. H. W. M. and Kačaki, J. (1974). Reversed haemagglutination test for the detection of hepatitis B antigen. Vox Sang. (Basel), 27, 97-114.

Schuurs, A. H. W. M. and Wolters, G. (1975). Hepatitis B surface antigen and human serum proteins. Amer.J. med. Sci., 270, 173-177.

van Weemen, B. K. and Schuurs, A. H. W. M. (1971). Immunoassay using antigen-enzyme conjugates. FEBS Letters, 15, 232-236.

van Weemen, B. K. and Schuurs, A. H. W. M. (1972). Immunoassay using hapten-enzyme conjugates. FEBS Letters, 24, 77-81.

van Weemen, B. K., Schuurs, A. H. W. M., Oostermeijer, M. W., and Raymakers, H. H. T. (1974). Immunoassay using antibody-enzyme conjugates. FEBS Letters, 43, 215-218.

World Health Organization (1975). Viral hepatitis (report of a WHO meeting). Wld Hlth Org. techn. Rep. Ser., 570. 